https://doi.org/10.31470/2706-7904-2020-15-54-58

\title{
CORONAVIRUS CONCEPT RESEARCH THROUGH PSYCHOLINGUISTIC LENSES
}

\section{Дослідження концепту «пандемія коронавірусу» за допомогою психолінгвістичного інструментарію}

\author{
Olena Goroshko \\ Doc Hub in Linguistics and Sociology, Professor \\ National Technical University «Kharkiv Polytechnic Institute» (Ukraine) \\ olena.goroshko1965@gmail.com \\ https://orcid.org/0000-0002-8592-1022
}

\begin{abstract}
The article reveal the perception of the concept of «coronavirus» in the linguistic consciousness of native speakers of Ukrainian. Using the method of free association test, ten associative fields to the words describing the concept of coronavirus: "Coronavirus, Covid-19, pandemic, social distance, lockdown quarantine, mask, tests, self-isolation, vaccine» are obtained. The data provide the clear picture with what the coronavirus concept associates in the mentality of Ukrainians. The negative stimuli linked with danger, uncertainty and illness are prevailed.
\end{abstract}

Key words: coronavirus concept, free associative test, mentality, Ukrainian.

\section{Introduction}

The corona pandemic impacts the human life drastically and the question «whether» normal life» is the same as it was before coronavirus», or when the world will be overwhelmed by the deadly virus, is questions that no one can answer definitively (Bárcena et al., 2009). A pandemic combines what is most difficult for a person to endure - the invisibility of the threat with the uncertainty of the situation. When you don't see something that can threaten you, you start seeking it everywhere. The uncertainty of the situation forces us to sort out alternatives and calculate the worst-case scenarios instead of concentrating on specific things and actions (Mikheeva, 2020). One can argue that the corona crisis may be unprecedented, but there are always patterns in how humans behave when thrust into long periods of isolation and danger. 
The world is getting closer to the pain and suffering caused by the outbreak of the coronavirus (simultaneous efforts by countries to detect the coronavirus vaccine), in fact, the sense of «national homeland» has been formed in the revival of the human conscience in the form of a common human spirit (Peiris et al., 2003).

Sociologists delineate some trends in this coronavirus situation impact:

We learn communicating only with the help of technical means and internettechnologies;

We have already begun to adopt a new format of solidarity;

There may be a problem with our physical practices;

We learn empathy and come out of our little social aquariums;

The role of governments is already being reconsidered;

We are already overestimating what we have (Mikheeva, 2020).

As the number of confirmed covid cases go on to rise, and public spaces across the globe remain practically closed, scholars argue that the coronavirus outbreak is having profound impacts on the personal lives of people in a variety of ways (Fisher, 2020; Nurbakova et al, 2020). Nearly nine-in-ten U.S. adults think that their life has changed at least a little as a result of the coronavirus, including $44 \%$ who declare that their life has changed drastically (Most Americans Say Coronavirus Outbreak Has Impacted Their Lives, 2020).

One can assert the pandemic becomes a bigger and bigger part of daily life, researchers are warning of changes in how we think, behave and relate to one another some temporary but others potentially permanent - could be the new normal (Baker, 2020).

Rapid social transformations cause changes in the inner world of personae, including his/her linguistic consciousness, which is most conducive to the impact of changes occurring in modern society and the world. Thus, in the linguistic consciousness of the native speaker of the Ukrainian language are developed their own, different from the ideas inherent, for example, Poles or Germans, in relation to various aspects of the impact of the pandemic on society and its consequences.

That is why the research with what is linked the coronavirus concept in our linguistic consciousness is of high topicality.

\section{Methods and Techniques of the Research}

Peculiarities of reflecting the concept of a pandemic in the linguistic consciousness, in our opinion, may indicate the inner meanings expressed by personal and professional values, ideas about personality traits and attitudes to this phenomenon in general. It is considered that one of the most effective tools for studying language consciousness is an associative experiment (Goroshko, 2003). However, due to the complexity in defining and 
studying this concept, it is recommended to use several methods at the same time, e.g. free and chain associative tests, semantic differential, J. Kelly personal constructs methods to increase data validation. It should be noted that the use at the same time of several methods allows to identify both universal and specific in such a complex subject for indirect research as the linguistic consciousness.

Thus, at the first stage of the empirical study, a free associative test was conducted to identify in the language consciousness. The proposed stimuli Coronavirus, Covid-19, pandemic, social distance, lockdown quarantine, mask, PCR tests, self-isolation, vaccine" describing the Coronavirus pandemic concept are selected. We consider that they are used more frequently in describing pandemic and linked with it.

Instruction for conducting a free associative experiment online is the following: Participants are asked to answer the first word that came to their minds when they read the stimulus. All answers are registered in Google form.

Using this method 10 associative fields are obtained. As it is a pilot study so the sample consists of 150 informants - native speakers of Ukrainian. There are $40 \%$ of males and $60 \%$ - females.

\section{Results}

We present an analysis of the kernels of 10 associative fields, collected for 10 proposed stimuli. The associative kernels include reactions with a frequency of more than 2 .

Pandemic - horror 14, what to do 13, don't want 13, china 10, death, vaccine, mask, testing, hospital 5, oxygen, bat, covid, panic 4, people, closed, all, life 3.

Coronavirus - symptoms 13, test, temperature 12, PCR 11, self-isolation 10, mask 9, distance, houses 8 , code, blood, hospital, bed 7 , headache 6 , patient 5 , oxygen 4 , ventilation 3 .

Social distance - with coronavirus 14, mask, test, one and a half meters 13, what is 10, code, temperature, cough, hospital 9, room 8, oxygen, blood, vaccine 7, pass 6, go, difficult 5, well, that's 4 .

Lockdown - bad 12, restrictions, tough, idiocy 10, life 9, I don't want, why, need 7, and what to do 6, corona, infection, hospital 5, safety 4, life, fear, why, to lock sit, our reality, AVL (ventilator) 3.

Covid - 19 - quarantine 11, bad, I can't, I don't want, I have to 10, life, hospital, covid 6, mask, metro 5, transport, school, study, distance, restrictions, again, around 4, house, death, people, shock, insanity 3.

Mask - buy, need, covid 9, crown, beech, respirator, protection 8, wear, be sure 7, nowhere, life, need, reality 6, change, need, own, removed 5, put on, test 4, PCR, torn, thrown away, disposable, pain, ward, hospital, operation 3. 
Quarantine - corona 15, horror, necessary 12, everyone, everywhere, transport 9, subway, shop, mask 7, tests, got sick, died 5, I don't know, covid, enter 4, country, fly in, border, annoyed everyone, darkness, life, died, analyzes, mask mode 3.

Self isolation - went 13, left, covid 12, coronavirus, needed, at home 11, sitting 10, survived, illness, hospital 7, home, loved ones, media 5, panic, facebook 4, mask, test, sick, our time, trip 3.

Vaccine - need, vaccination 12, decision 11, pandemic, be sure, conduct 10, all, children, why 7, pfizer, moderna 6, England 5, vaccination, tests, expensive, start, corona, pandemic, stop 3.

PCR test - need, required 12, why 11, be sure, vaccination 10, covid, corona 9, pandemic 8, hospital, ELISA 5, laboratory, did 4, a lot, test everyone, risk group, I see 3.

\section{Conclusions}

The kernels of associative fields obtained show a high percentage of negative reactions and a stereotyped behavioral response. The negative stimuli linked with danger, uncertainty and illness are prevailed. We don't reveal practically positively colored reactions.

In the future, it is planned to collect reactions from 1000 informants in order to obtain an associative norm for the concept of coronavirus pandemic.

It is also planned to conduct a comparative study in Poland and Germany in order to obtain a more accurate picture of how the coronavirus pandemic is reflected in the linguistic consciousness of representatives of a particular culture.

Additionally, we plan to conduct research by the method of Semantic Differential with the same stimuli.

\section{References}

Baker, P.C. (2020). We can't go back to normal': how will coronavirus change the world? Guardian. https://www.theguardian.com/world/2020/mar/31/how-will-the-world-emergefrom-the-coronavirus-crisis

Bárcena, M., Oostergetel, G.T., Bartelink, W., Faas, F.G., Verkleij, A., Rottier, P.J., \& Bosch, B.J. (2009). Cryo-electron tomography of mouse hepatitis virus: insights into the structure of the coronavirion. Proceedings of the National Academy of Sciences, 106(2), 582-587.

Goroshko, E.I. (2003). Jazykovoe soznanie: gendernaja paradigm [Linguistic Consciousness: Gender Paradigm]. Moscow-Harkov: IJa RAN-ID «INZhJeK» [in Russian].

Fisher, M. (2020). What Will Our New Normal Feel Like? Hints Are Beginning to Emerge. The New York Times. https://www.nytimes.com/2020/04/21/world/americas/coronavirus-socialimpact.html 
Mikheeva, O. (2020). Ukrainske suspilstvo ta koronavirus: yak pandemiya zminyuє kozhnogo z nas zseredini [Ukrainian Society and Coronavirus: How a Pandemic Chanes each of us inside]. Radio Svoboda. https://www.radiosvoboda.org/a/30510549.html [in Ukrainian].

Nurbakova, D, Ermakova, L., \& Ovchinnikova, I. (2020). Understanding the Personality of Contributors to Information Cascades in Social Media in Response to the COVID-19 Pandemic. Proceedings of the Conference: SENTIRE'20 @ ICDM 2020 At: Sorrento. https://www.researchgate.net/publication/344626820 Understanding the Personality of C ontributors_to_Information_Cascades_in_Social_Media_in_Response_to_the_COVID19 Pandemic

Most Americans Say Coronavirus Outbreak Has Impacted Their Lives (2020). Pew Research Center https://www.pewsocialtrends.org/2020/03/30/most-americans-say-coronavirusoutbreak-has-impacted-their-lives/

Peiris, J.S.M., Lai, S.T., Poon, L.L.M., Guan, Y., Yam, L.Y.C., Lim, W., ... Cheng, V.C.C. (2003). Coronavirus as a possible cause of severe acute respiratory syndrome. The Lancet, 361(9366), 1319-1325.

The struggles vegetable vendors face (2020). The Economic Times. Politics. https://economictimes.indiatimes.com/news/politics-and-nation/coronavirus-the-strugglesvegetable-vendors-face/lockdown/slideshow/75290296.cms 